\title{
[ Selected Bibliography of the Publications of Professor Stanislav J. Kavka ]
}

\section{Miroslav Černý}

University of Ostrava, Ostrava, Czech Republic

[Abstract] The paper presents a bibliography of the publications of Professor Stanislav Jindrich Kavka (1946-2015), a renowned Czech Anglicist and comparative linguist. The bibliography was compiled on the occasion of what would have been the year of his $75^{\text {th }}$ birthday. It is meant to serve as a modest contribution to the history of English studies in Central Europe.

[Keywords] Stanislav J. Kavka; bibliography; English studies; linguistics 


\section{[1974]}

Ordering in a String of Pre-Modifying Attributes in Present-Day English. Brno: University of J. E. Purkyně. (Unpublished dissertation)

K problému rozdělování slov na konci řádku v angličtině [On the Problem of Dividing

Words at the End of a Line in English]. Cizí jazyky ve škole, XVII, 255-257.

\section{[1975]}

Cizí jazyk a logické nazírání [A Foreign Language and the Logical View]. Cizí jazyky ve škole, XVIII, 175-177.

\section{[1976]}

English Compounds Revisited. Acta Facultatis Paedagogicae Ostraviensis, 48, 99-105. K užívání apostrofu v angličtině [On the Use of the Apostrophe in English]. Cizí jazyky ve škole, XIX, 444-447.

\section{[1977]}

A Note on Semantic Determination within the String of Pre-Modifying Attributes. Acta Facultatis Paedagogicae Ostraviensis, 53, 35-47.

O velkých písmenech a spojovnících v angličtině [On Capital Letters and Hyphens in English]. Cizí jazyky ve škole, XX, 357-361.

Znáte termín ‘subjunktiv'? [Do You Know the Term 'Subjunctive'?] Cizí jazyky ve škole, $\mathrm{XX}, 408-411$.

\section{[1978]}

K některým směrům fonologie [On Some Trends and Directions in Phonology]. Cizí jazyky ve škole, XXI, 443-449.

\section{[1979)}

Deep Structure of the English and Czech Noun-Phrase: An Introductory Study. Acta Linguistica Silesiana, 3, 117-128.

Some Major Problems of Attributive Position. Acta Facultatis Paedagogicae Ostraviensis, 64, 5-13.

Zamyšlení nad stavem jazykových znalostí v podnikové sféře: Výsledky dotazníkového šetření [Reflections on the State of Language Competence in a Company Environment: Results of a Questionnaire Investigation]. Cizí jazyky ve škole, XXII, 104-108. 


\section{[1980]}

Semantic Determinations within the Noun Phrase in Modern English and Spanish. Praha: Státní pedagogické nakladatelství.

Vybrané kapitoly z fonologie [Selected Chapters from Phonology]. Ostrava: Pedagogická fakulta v Ostravě.

How to Consciously Make English Sound English. Acta Facultatis Paedagogicae Ostraviensis, 69, 5-11.

\section{[1984]}

Fonetika a fonologie [Phonetics and Phonology]. Ostrava: Pedagogická fakulta v Ostravě. Reprint in 1994 and 2004.

\section{[1985]}

The Role of Linguistics in Controlling Language Communication. In J. Hoffmannová and D. Viehweger (Eds.) Linguistische und sozialpsychologische Analyse der mündlichen Kommunikation (pp. 143-147). Praha: Czechoslovak Academy of Sciences. (Co-author Josef Skácel)

Further Notes on Conscious Mastering of Foreign Languages. Acta Facultatis Paedagogicae Ostraviensis, 93, 77-83.

\section{[1986]}

Language Planning Implications in a Socialist Society. In J. Chloupek and J. Nekvapil (Eds.) Reader in Czech Sociolinguistics (pp. 257-273). Praha: Academia. (Co-author Josef Skácel)

Language for Special Purposes Programs as Implementation of Language Planning. Acta Facultatis Paedagogicae Ostraviensis, D 23, 17-21.

Negation in English and Czech Revisited. Acta Facultatis Paedagogicae Ostraviensis, D 23, 23-32. (Co-author Eva Kavková)

Nová kniha o pragmalingvistice [A New Book on Pragmalinguistics]. Slovo a slovesnost, 1, 59-62. (Book review)

Pohledy holandské a belgické sociolingvistiky [Views of Dutch and Belgian Sociolinguistics]. Slovo a slovesnost, 3, 253-255. (Book review)

\section{[1987]}

Linguistics and Language Planning: On the Concept of 'Language Situation'. Acta Facultatis Paedagogicae Ostraviensis, D 24, 25-30.

On Some Language Microplanning Elaboration Problems: Opening the Research Problem. Acta Facultatis Paedagogicae Ostraviensis, D 24, 31-39. (Co-author Eva Kavková) 


\section{[1988]}

An Outline of Modern Czech Grammar. Uppsala: Uppsala Universitet.

\section{[1989]}

Inledning till tjeckisk litteraturhistoria. Uppsala: Uppsala Universitet.

On Some Problems of Attribute Position in English and Czech: An Attempt at a Contrastive Czech-English Approach. Slovo: Journal of Slavic Languages and Literatures, 37, 67-82.

\section{[1990]}

Mluvená a psaná forma současné angličtiny [The Spoken and Written Forms of Present-Day English]. Ostrava: Pedagogická fakulta v Ostravě.

\section{[1991]}

Úvod do anglistiky [An Introduction to English Linguistics]. Ostrava: Pedagogická fakulta v Ostravě.

\section{[1993]}

Nástin dějin anglického jazyka [An Outline History of the English Language]. Ostrava: Ostravská univerzita.

Mluvená a psaná forma současné angličtiny [The Spoken and Written Forms of Present-Day English]. $2^{\text {nd }}$ edition. Ostrava: Ostravská univerzita.

\section{[1995]}

The English Verb: A Functional Approach. Ostrava: Ostravská univerzita.

\section{[1998]}

Some Remarks on the Vowels of English, German and Czech. In: Zbornik Fakulty humanitních vied, sekcia filologická 2 (pp. 172-179). Banská Bystrica: University Mateja Bela. (Co-author Karl Odwarka)

\section{[1999]}

My Dear Colleagues. In European British and American Studies at the Turn of Millenium (pp. 5-5). Ostrava: University of Ostrava. (Introduction) 
Some Aspects of Idiomaticity. In European British and American Studies at the Turn of Millenium (pp. 101-105). Ostrava: University of Ostrava.

Foreign Language Teaching. In European British and American Studies at the Turn of Millenium (pp. 171-171). Ostrava: University of Ostrava. (Afterword)

1989 - Revival of the Department. In European British and American Studies at the Turn of Millenium (pp. 173-174). Ostrava: University of Ostrava.

\section{[2000]}

Morphology. In P. Štekauer (Ed.) Rudiments of English Linguistics 1 (pp. 61-92). Prešov: Slovacontact.

Some Hints on the Importance of Teaching Idiomaticity. Studia Anglica Posnaniensia, 35, 205-216.

\section{[2002]}

On the Idiomatic Status of English Compounds. Studia Anglica Posnaniensia, 37, 119-129. A Few Psycholinguistic Notes on English Compounds. In A. Grmelová and M. Farrell (Eds.). Prague Conference on Linguistics and Literary Studies (31-38). Prague: Charles University.

\section{[2003]}

English Linguistics for Novices: An Introductory Course. Ostrava: University of Ostrava. A Book on Idiomatology. Žilina: University of Žilina.

Rudiments of English Linguistics 2. Prešov: Slovacontact. (Co-editor Pavol Štekauer) A Basic Course in Idiomatology. Ostrava: University of Ostrava. (E-learning material) Idiomatology. In P. Štekauer and S. Kavka (Eds.) Rudiments of English Linguistics 2 (pp. 149-203). Prešov: Slovacontact.

English Compounds (Revisited) as Idiomatic Expresions and Continua. Linguistica Pragensia, 1, 17-33.

Inflectional and/versus Derivational Morphology: Clear-Cut Types or Continua? Studia Anglica Posnaniensia, 39, 177-189.

\section{[2004]}

Glimpses on the History of Idiomaticity Issues. SKASE Journal of Theoretical Linguistics, 1, 54-66. (Co-author Jerzy Zybert)

Cesta k moderní španělštině: Pomocný učební materiál pro seminář historické mluvnice španělštiny [Modern Spanish in the Light of Language Change: A Supplementary Study Text for Seminars in Historical Spanish Grammar]. Ostrava: Ostravská univerzita. 


\section{[2005]}

Notes on Research into Idiomatology. Scripta Neophilologica Posnaniensia, VII, 277-286.

(Co-author Jerzy Zybert)

Another Fifteen Years of English Philology in Ostrava. Studia Anglica, 1, 5-6.

\section{[2006]}

Compounds and Compounding: An Attempt at a Complex View. Ostrava: University of Ostrava. (Co-author Pavol Štekauer)

A Note on 'Omnipotence' of Context: Its Impact on Comprehending Idiomatic Expressions. Studia Anglica, 2, 7-24.

A Way of Mastering Idiomatic English: How to Approximate the Ideal? In Pocta Evě Mrhačové (pp. 111-115). Ostrava: Ostravská univerzita.

\section{[2007]}

Past and Present of the English Language. Ostrava: University of Ostrava. Reprint in 2009. Fonetika i fonologia ogólna i kontrastywna [General and Contrastive Phonetics and Phonology]. Racibórz: Państwowa Wyższa Szkoła Zawodowa. (Co-authors Jacek Molęda and Andrzej Widota)

\section{[2008]}

Will Linguists Ever Arrive at an Agreement about the Compound Status? A Few Remarks with Special Regards to Spanish Compounds. Studia Romanistica, 8, 27-35. Jarmila Tárnyiková, Sentence Complexes in Text: Processing Strategies in English and in Czech. Linguistica Pragensia, 2, 101-106. (Book review)

\section{[2009]}

Modern English Phonemics. Lódź: Wydawnictwo Akademii Humanistyczno-Ekonomicznej.

English Linguistics for Novices: An Introductory Course. 2nd edition. Ostrava: University of Ostrava.

Compounding and Idiomatology. In P. Štekauer and R. Lieber (Eds.) The Oxford Handbook of Compounding (pp. 19-33). Oxford: Oxford University Press.

Whims of Context in the Interpretation of Idiomatic Expressions. In M. Procházka, M. Malá and P. Šaldová (Eds.) The Prague School and Theories of Structure (pp. 219-227). Goettingen: V\&R Unipress.

A Few Whims of the Old English Prefix ge- Revisited. Ostrava Journal of English Philology, 1, 54-66. (Co-author Miroslav Černý) 


\section{[2010]}

The English Verb. 2nd edition. Racibórz: Państwowa Wyższa Szkoła Zawodowa.

Za profesorem Alešem Svobodou. Listy Ostravské univerzity, 1, 23-23. (Obituary for Professor Aleš Svoboda)

\section{[2011]}

New Chapters in Functional Syntax. Ostrava: University of Ostrava. (Co-editors Miroslav Černý, Jana Chamonikolasová and Eva Klímová)

Foreword. In M. Černý, J. Chamonikolasová, S. Kavka and E. Klímová (Eds.) New Chapters in Functional Syntax (pp. 7-8). Ostrava: University of Ostrava.

\section{[2013]}

Selected Studies in English Linguistics. Racibórz: Państwowa Wyższa Szkoła Zawodowa. Praktické rady z anglické fonetiky [Practical Advice on English Phonetics]. Ústí nad

Labem: Network of Educators of Foreign Language Teachers. (E-learning material) Idioms and Their Potential Lexical Extension. Current Language and Literature Studies, 11, 150-158.

\section{[2015]}

Semantics, Around and Beyond: An Introductory Course. Žilina: University of Žilina.

\section{[2019]}

Stručné dějiny angličtiny [A Brief History of English]. Ostrava: Ostravská univerzita. (Co-author Miroslav Černý)

\section{[Address]}

Department of English and American Studies

Faculty of Arts

University of Ostrava

Reální 5

70103 Ostrava

Czech Republic

miroslav.cerny@osu.cz

Miroslav Černy is Associate Professor at the Department of English and American Studies at the University of Ostrava's Faculty of Arts. He specializes in sociolinguistics, language development, and Native American literature and culture. His previous publications include Sociolinguistic 
and Pragmatic Aspects of Doctor-Patient Communication (2007) and Discourse of Medicine Revisited: On Conveying Empathy and Trust in English Medical Consulting (2012). He is a co-editor of New Chapters in Functional Syntax (2011) and Collected Works of Jan Firbas II, III (2013, 2014). 